Article

\title{
Savings-Group Improvements Contribute to Sustainable Community-Fisheries Management: A Case Study in Cambodia
}

\author{
Sopha Lieng ${ }^{1, *(\mathbb{D},}$, Nobuyuki Yagi ${ }^{1}$, Aimee Mori ${ }^{1}$ and Jay D. Hastings ${ }^{2}$ \\ 1 Graduate School of Agricultural and Life Sciences, The University of Tokyo, Tokyo 113-8657, Japan; \\ yagi@fs.a.u-tokyo.ac.jp (N.Y.); aimee.mori246@gmail.com (A.M.) \\ 2 Sustainable Communities International (SCI), 1676 Parkview Drive Northeast Bainbridge Island, WA 98110, \\ USA \\ * Correspondence: liengsopha@gmail.com; Tel.: +81-3-5841-7501
}

Received: 23 July 2018; Accepted: 10 August 2018; Published: 16 August 2018

\begin{abstract}
Small-scale community fishers dominate fisheries in Cambodia. In the central floodplain of Cambodia, 35\% of rural dwellers are part-time fishers and 15\% full-time fishers. By 2012, the Cambodian government had abolished all commercial fishing lots and put these resources under the management of community fisheries. One challenge in the implementation of community-fisheries management is budget shortages and resultant livelihood stress. To address this problem, savings groups were established. The Sustainable Communities International program provided establishment and facilitation support for savings groups in 10 community fisheries in the Kampong Chhnang Province. The savings groups were recognized as useful support facilities, meeting the needs of community fishers and sustainable community fisheries operations. However, there were concerns about the sustainability of the savings groups and the fisheries. To date, there are no documented case studies of savings groups for community fisheries. This study was conducted in two community fisheries in the Kampong Chhnang Province. We found that the internal rules of the savings group must reflect the opinions and perceptions of the members to ensure sustainable operation. Education and integrated livelihood activities were important considerations in encouraging participation. These insights are also useful for community fisheries elsewhere.
\end{abstract}

Keywords: small-scale fisheries; savings group; livelihood; sustainability; community fisheries

\section{Introduction}

Rice and fish are staple Cambodian foods and have a long history in Khmer culture [1]. Cambodian fisheries are mainly freshwater fisheries. Most rural Cambodians are both farmers and part-time fishers, with the fisheries providing food and family income. Cambodia still has a high poverty rate, although it has dropped from $47.8 \%$ in 2007 to only 13.5\% in 2016 [2]. Fishing is easy to start and only requires a small capital input. The number of fishers has subsequently increased [3]. In the 1940s, when the Cambodian population was 3.2 million, there were 0.36 million fishers [4]. As the population increased to 10.7 million in 1995, the number of fishers increased to 1.2 million [4]. However, fish catches have gradually declined [1,5-7]. Fisheries were affected by habitat and environmental degradation and destructive fishing practices, as well as the increase in fishing effort [4]. Conflicts occurred between villagers and fishing-lot owners [8]. In 2001, the Cambodian government introduced fisheries reform, abolished all fishing lots in 2012, and handed the resources over to rural fishers to manage under community fisheries. Under fishery-policy reform and the decentralization and deconcentration policy of the Royal Government of Cambodia, community fisheries have been given the responsibility of 
managing their exclusive fishery zones and utilizing these fishery resources for their livelihood needs in a sustainable manner [9]. These community fisheries must design and implement an action plan to conserve and manage fishery resources in their exclusive fishery areas [9].

However, there were many challenges in the implementation of community-fisheries management. Community fishers have very limited capacities to implement community fisheries and exercise their fishery rights. Lack of funds to implement comanagement and conservation plans, such as patrolling for illegal fishing and protecting fish stocks, can be another challenge for community fisheries. There was high fishing pressure. Law enforcement was not so effective. Furthermore, destructive fishing practices occurred in many locations, fish catches per fisher declined, and fish habitats gradually degraded. Flooded forests, which are an important element of fish habitats, were cleared for agricultural land and firewood. They were also intentionally burned for hunting or lost to other accidental fires. Climate change increased flooding and drought, which caused fish to die off in the dry season. Participation in community-fisheries management was very limited owing to poverty and budget constraints. Community fishers led stressful lives and poverty discouraged their participation in community-based fishery management.

Community fishers can apply for loans from several sources for their family needs. Private loans and many microfinance institutions, such as ACLEDA Bank Plc., Hattha Kaksekar Ltd., PRASAC Microfinance Institution Ltd., AMK Microfinance Institution Plc., and VisionFund provide loans to rural communities. Savings groups are groups of people who establish a secure place for borrowing and saving money. The amount of money depends on the ability of the group. Loans are given to group members at low interest rates and without collateral. Savings groups have been established in many community fisheries [10]. The Sustainable Communities International program co-operated with the Cambodian Fisheries Administration's Department of Community Fisheries Development to help build 10 community fisheries in the Kampong Chhnang Province of Cambodia. The program assisted in establishing and strengthening community-fisheries savings groups to meet the urgent budget needs of fishers and contribute to sustainable fisheries management [3]. Community members readily welcomed the savings groups. However, previous studies do not document the success and failure of savings groups in community fisheries, although one study by OXFAM about savings groups in agriculture was published in 2012 [11].

There are several potential problems related to current savings groups. Members may disagree about access to loans or the capacity of committee members or leaders [11]. Some members may be unable to procure loans [11]. Fishers invest the loan amounts in purchasing fishing gear, gas, small businesses, house repairs, boat repairs, and in meeting urgent family needs. Therefore, these loans are not only used for the benefit of community fisheries, but also for the personal needs of individual members. Therefore, studies on savings groups in these community fisheries would provide a more comprehensive understanding of these facilities and highlight important considerations for improving the implementation of savings groups and community fisheries in the Kampong Chhnang Province. The results from this study could also be beneficial to community fisheries in other areas. The objectives of this study are to explore the livelihood activity, fishery resources, and management characteristics of two rural community fisheries, Peam Popech and Phlong, in the Kampong Chhnang Province, and to understand the community members' perception of savings groups and loans in these two community fisheries.

\section{Materials and Methods}

\subsection{Study Sites}

This study was formulated to seek the perceptions of two rural community fisheries about how to improve the implementation and arrangement of their savings groups. Two community fisheries were selected from the 10 communities located in the Tonle Sap floodplain supported by the Sustainable Communities International program. The selection of the two communities was discussed with local 
fisheries officers for convenient access and communication. They had no distinct characteristics. Descriptions of the two chosen community fisheries are as follow:

\subsubsection{Peam Popech Community Fishery}

This community fishery was established on 16 February 2005 and is located in Peam Popech Village, Kaoh Thkov Commune, Chol Kiri District, Kampong Chhnang Province, Cambodia (Figure 1). At the time of this study, the village had a population of 1428 , which is equivalent to 267 households. The community fishery was managed by 11 committee members. All 11 committee members were also members of the savings group. The committee met 2-3 times per month to discuss issues, such as the action plan, to make implementation arrangements, plan fishery patrolling if there were reports of fish poaching, or for conflict resolution. The community fishing ground extended for $1423 \mathrm{ha}$. The community's conservation areas covered 35 ha in the lacustrine zone and another, $3 \mathrm{~km}$ along a river and the width of the river. There were 15 patrolling members. Patrolling members carried out their patrol activities twice a week.

\subsubsection{Phlong Community Fishery}

The Phlong community fishery is in Phlong Village, Peam Chhkaok Commune, Chol Kiri District, Kampong Chhnang Province, Cambodia (Figure 1). The community was established in 1997, with 808 members in 209 households. It was managed by 13 members of the community-fisheries committee. The fishing ground of the community extended for 701 ha with 3 ha as a fish-conservation area. Flooded forest covered 25 ha of the community fishing ground. Patrolling members of the community carried out patrol duties to protect the fishery resources $3-4$ times per month.

\subsection{Data Collection and Analysis}

The data for this study were gathered using a questionnaire (Supplementary Questionnaire S1). The questionnaire was formulated to collect information about education, income, livelihood activities, rice and other cropland, fish consumption, the status of fishery resources, and the savings group. The information about farmland was collected because most members were farmers as well as fishers.

A total 160 households were opportunistically selected for interviewing, of which 77 households were in the Peam Popech community and 83 households in the Phlong community. This represented $29 \%$ and $40 \%$ of the total households, respectively. The participants in the interviews were $53 \%$ men and $47 \%$ women in the two communities, respectively. The interviews were conducted from 22-29 March 2016. Ms. Aimee Mori, from the University of Tokyo, designed and conducted the data collection. Fisheries officers of the Cambodian Fisheries Administration assisted in interviews with the community fishers.

The data were entered into Excel spreadsheets and examined using Pivot Tables (2016 Microsoft, Redmond, WA, USA). They were analyzed using descriptive statistics. The Chi-square test $\left(\mathrm{X}^{2}\right)$ was used to compare categorical data, such as age, education, income, livelihood activities, occupation, fish-consumption patterns, household assets (farm- and cropland), status of fisheries, engagement in social community, and the distribution pattern of savings and loans between the two study sites (Peam Popech and Phlong community fisheries) and between the dry and wet seasons with the significant level of 0.05 . 


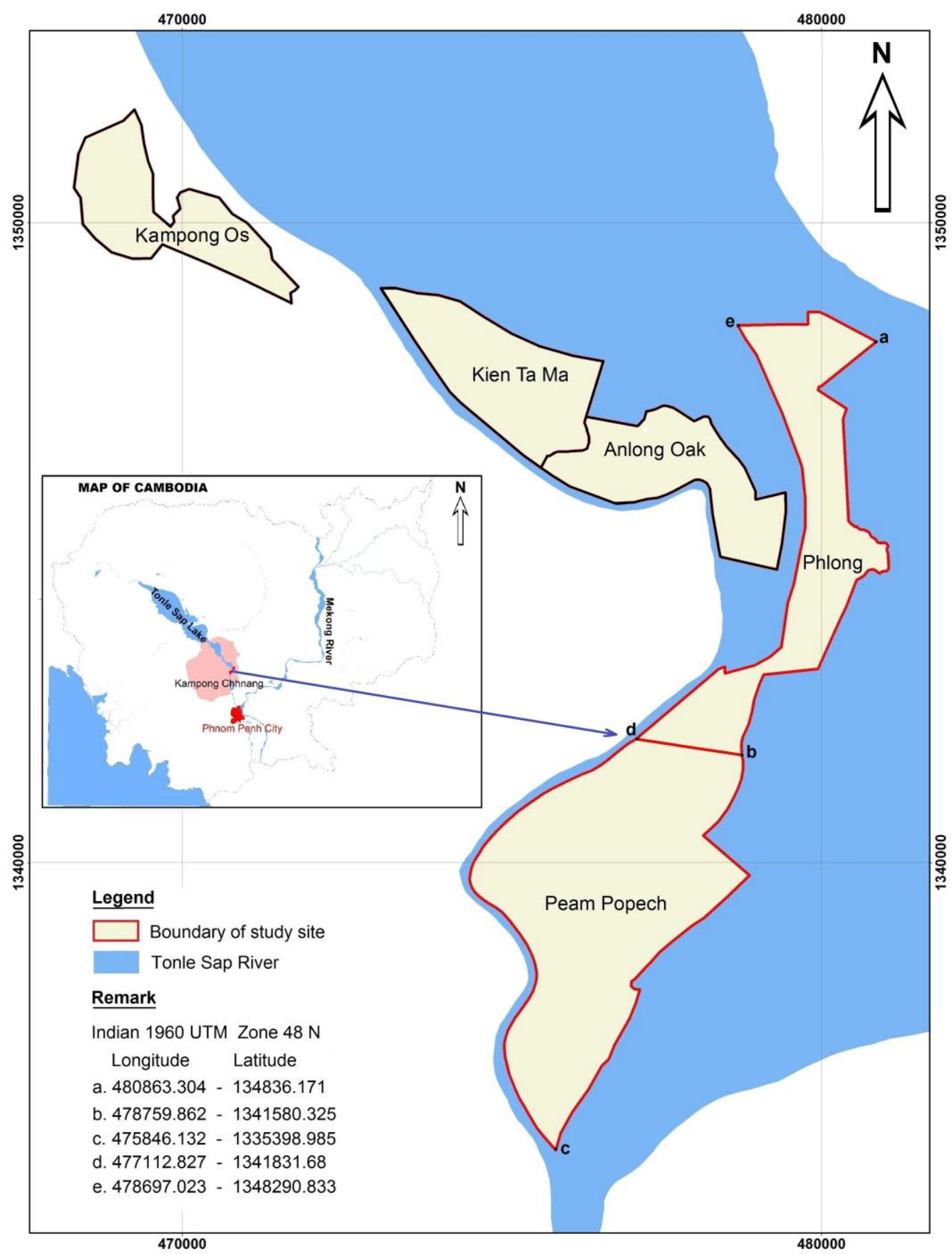

Figure 1. Map showing the locations of the Peam Popech and Phlong community fisheries. Source: map produced by Mr. Jotra Sou, Fishery Administration, Cambodia [12].

\section{Results}

The results of the study showed the characteristics of the community fisheries, fishery resources, and the savings groups in two community fisheries, namely Peam Popech and Phlong, in the Kampong Chhnang Province, Cambodia. The statistical results of the survey are presented in Tables 1 and 2 below. 
Table 1. Characteristics of the Peam Popech and Phlong community fisheries in the Kampong Chhnang Province, Cambodia.

\begin{tabular}{|c|c|c|c|c|}
\hline No. & Indicator & Variable & Peam Popech & Phlong \\
\hline \multicolumn{5}{|c|}{ 1. Characteristics of the community fisheries } \\
\hline 1.1. & $\begin{array}{c}\text { Community-fisheries } \\
\text { members }\end{array}$ & $\begin{array}{c}\text { Total number of community } \\
\text { fisheries members (households) }\end{array}$ & 267 & 209 \\
\hline 1.2 & Interviewees & $\begin{array}{l}\text { Total number of interviewees } \\
\text { (households): } 160 \text { households }\end{array}$ & 77 & 83 \\
\hline \multirow[t]{3}{*}{1.3} & Sex & Number of interviewees: & & \\
\hline & & Men & $35(47 \%)$ & 48 (59\%) \\
\hline & & Women & $40(53 \%)$ & $33(41 \%)$ \\
\hline \multirow[t]{8}{*}{1.4} & Age (years) & Number of people by age group & & \\
\hline & & $15-25$ & $3(3.9 \%)$ & $3(3.7 \%)$ \\
\hline & & $26-35$ & $10(13.0 \%)$ & $26(32.1)$ \\
\hline & & $36-45$ & $23(29.9 \%)$ & $16(19.8)$ \\
\hline & & $46-55$ & $31(40.3 \%)$ & $20(24.7)$ \\
\hline & & $56-65$ & $8(10.4 \%)$ & $12(14.8)$ \\
\hline & & $66-75$ & $1(1.3 \%)$ & $4(4.9 \%)$ \\
\hline & & $76-85$ & $1(1.3 \%)$ & $0(0 \%)$ \\
\hline \multirow[t]{6}{*}{1.5} & Education & $\begin{array}{l}\text { Education level of the } \\
\text { interviewees }\end{array}$ & & \\
\hline & & No education & $6(7.8 \%)$ & $13(16.7 \%)$ \\
\hline & & Not finished primary school & $43(55.8 \%)$ & $40(51.3 \%)$ \\
\hline & & Finished primary school & $14(18.2 \%)$ & $12(15.4 \%)$ \\
\hline & & Finished junior high school & $13(16.9 \%)$ & $13(16.7 \%)$ \\
\hline & & Finished senior high school & $1(1.3 \%)$ & $0(0 \%)$ \\
\hline \multirow[t]{5}{*}{1.6} & $\begin{array}{l}\text { Household income from } \\
\text { fishing in dry season }\end{array}$ & $\begin{array}{l}\text { Number of households getting } \\
\text { income from fishing }\end{array}$ & & \\
\hline & & No income from fishing & $19(26 \%)$ & $16(19.3 \%)$ \\
\hline & & $0-30 \%$ & $45(61.6 \%)$ & $45(54.2 \%)$ \\
\hline & & $30-70 \%$ & $9(12.3 \%)$ & $21(25.3 \%)$ \\
\hline & & $70 \%$ up & $0(0 \%)$ & $1(1.2 \%)$ \\
\hline \multirow[t]{5}{*}{1.7} & $\begin{array}{l}\text { Household income from } \\
\text { fishing in wet season }\end{array}$ & $\begin{array}{l}\text { Number of households getting } \\
\text { income from fishing }\end{array}$ & & \\
\hline & & No income from fishing & $18(24.7 \%)$ & $16(19.3 \%)$ \\
\hline & & $0-30 \%$ & $45(61.6 \%)$ & $40(48.2 \%)$ \\
\hline & & $30-70 \%$ & $9(12.3 \%)$ & $24(28.9 \%)$ \\
\hline & & $70 \%$ up & $1(1.4 \%)$ & $3(3.6 \%)$ \\
\hline \multirow[t]{10}{*}{1.8} & $\begin{array}{c}\text { Livelihood activities in } \\
\text { wet season }\end{array}$ & $\begin{array}{l}\text { Number of households that } \\
\text { received income from different } \\
\text { livelihood activities in wet season }\end{array}$ & & \\
\hline & & Rice farming & $63(29.4 \%)$ & $64(30.5 \%)$ \\
\hline & & Crops & $41(19.2 \%)$ & $17(8.1 \%)$ \\
\hline & & Factory worker & $10(4.7 \%)$ & $10(4.8 \%)$ \\
\hline & & Construction worker & $9(4.2 \%)$ & $10(4.8 \%)$ \\
\hline & & Fish trade & $16(7.5 \%)$ & $20(9.5 \%)$ \\
\hline & & Fish processing & $12(5.6 \%)$ & $15(7.1 \%)$ \\
\hline & & Fishing gear making & $0(0 \%)$ & $0(0 \%)$ \\
\hline & & Livestock & $41(19.2 \%)$ & $51(24.3 \%)$ \\
\hline & & Other & $23(10.7 \%)$ & $23(11.0 \%)$ \\
\hline \multirow[t]{10}{*}{1.9} & $\begin{array}{l}\text { Livelihood activities in dry } \\
\text { season }\end{array}$ & $\begin{array}{l}\text { Number of households that } \\
\text { received income from different } \\
\text { livelihood activities in dry season }\end{array}$ & & \\
\hline & & Rice farming & $9(6.4 \%)$ & $9(6.3 \%)$ \\
\hline & & Crops & $10(7.1 \%)$ & $4(2.8 \%)$ \\
\hline & & Factory worker & $8(5.7 \%)$ & $8(5.6 \%)$ \\
\hline & & Construction worker & $12(8.5 \%)$ & $12(8.3 \%)$ \\
\hline & & Fish trade & $17(12.1 \%)$ & $21(14.6 \%)$ \\
\hline & & Fish processing & $11(7.8 \%)$ & $13(9 \%)$ \\
\hline & & Fishing gear making & $5(3.5 \%)$ & $0(0 \%)$ \\
\hline & & Livestock & $35(24.8 \%)$ & $48(33 \%)$ \\
\hline & & Other & $34(24.1 \%)$ & $29(20.1 \%)$ \\
\hline
\end{tabular}


Table 1. Cont.

\begin{tabular}{|c|c|c|c|c|}
\hline No. & Indicator & Variable & Peam Popech & Phlong \\
\hline 1.10 & Occupation in dry season & $\begin{array}{c}\text { Number of occupations per } \\
\text { household in dry season } \\
0 \text { occupation } \\
1 \text { occupation } \\
2 \text { occupations } \\
3 \text { occupations } \\
4 \text { occupations } \\
5 \text { occupations }\end{array}$ & $\begin{array}{c}4(5.2 \%) \\
27(35.1 \%) \\
29(37.7 \%) \\
12(15.6 \%) \\
5(6.5 \%) \\
0(0 \%)\end{array}$ & $\begin{array}{c}7(8.4 \%) \\
33(39.8 \%) \\
25(30.1 \%) \\
12(14.5 \%) \\
5(6.0 \%) \\
1(1.2 \%)\end{array}$ \\
\hline 1.11 & Occupation in wet season & $\begin{array}{c}\text { Number of occupations per } \\
\text { household in wet season } \\
0 \text { occupation } \\
1 \text { occupation } \\
2 \text { occupations } \\
3 \text { occupations } \\
4 \text { occupations } \\
5 \text { occupations } \\
6 \text { occupations }\end{array}$ & $\begin{array}{c}0(0 \%) \\
4(5.2 \%) \\
30(39.0 \%) \\
26(33.8 \%) \\
12(15.6 \%) \\
4(5.2 \%) \\
1(1.3 \%)\end{array}$ & $\begin{array}{c}1(1.2 \%) \\
10(12.0 \%) \\
30(36.1 \%) \\
30(36.1 \%) \\
9(10.8 \%) \\
2(2.4 \%) \\
1(1.2 \%)\end{array}$ \\
\hline 1.12 & $\begin{array}{l}\text { Fish consumption in dry } \\
\text { season }\end{array}$ & $\begin{array}{l}\text { Number of households that } \\
\text { reported different weekly } \\
\text { consumption levels of fish in dry } \\
\text { season } \\
\text { Not consumed } \\
\text { Less than } 3 \text { days } \\
3-5 \text { days } \\
\text { Everyday }\end{array}$ & $\begin{array}{c}1(1.3 \%) \\
1(1.3 \%) \\
40(53.3 \%) \\
33(44.0 \%)\end{array}$ & $\begin{array}{c}1(1.2 \%) \\
3(3.7 \%) \\
44(54.3 \%) \\
33(40.7 \%)\end{array}$ \\
\hline 1.13 & $\begin{array}{l}\text { Fish consumption in wet } \\
\text { season }\end{array}$ & $\begin{array}{l}\text { Number of households that } \\
\text { reported different weekly } \\
\text { consumption levels of fish in wet } \\
\text { season } \\
\text { Not consumed } \\
\text { Less than } 3 \text { days } \\
3-5 \text { days } \\
\text { Everyday }\end{array}$ & $\begin{array}{c}0(0 \%) \\
5(6.5 \%) \\
32(41.6 \%) \\
40(51.9 \%)\end{array}$ & $\begin{array}{c}2(2.4 \%) \\
2(2.4 \%) \\
33(39.8 \%) \\
46(55.4 \%)\end{array}$ \\
\hline 1.14 & Household assets & $\begin{array}{l}\text { Size of owned farmland (ha) * } \\
\qquad 0-0.5 \\
0.5-1 \\
1-1.5 \\
1.5-2 \\
2-2.5 \\
3-3.5 \\
4-4.5 \\
4.5-5\end{array}$ & $\begin{array}{c}3(4.2 \%) \\
13(18.3 \%) \\
32(45.1 \%) \\
9(12.7 \%) \\
10(14.1 \%) \\
4(5.6 \%) \\
0(0 \%) \\
0(0 \%)\end{array}$ & $\begin{array}{c}21(32.8 \%) \\
7(10.9 \%) \\
10(15.6 \%) \\
5(7.8 \%) \\
8(12.5 \%) \\
9(14.1 \%) \\
2(3.1 \%) \\
2(3.1 \%)\end{array}$ \\
\hline 1.15 & & $\begin{array}{l}\text { Size of owned cropland (ha) } \\
\qquad 0-0.5 \\
0.5-1 \\
1-1.5 \\
1.5-2 \\
2-2.5 \\
2.5-3 \\
3-3.5 \\
3.5-4\end{array}$ & $\begin{array}{l}6(12.5 \%) \\
13(27.1 \%) \\
18(37.5 \%) \\
2(4.2 \%) \\
6(12.5 \%) \\
1(2.1 \%) \\
1(2.1 \%) \\
1(2.1 \%)\end{array}$ & $\begin{array}{c}1(5.3 \%) \\
5(26.3 \%) \\
10(52.6 \%) \\
1(5.3 \%) \\
1(5.3 \%) \\
1(5.3 \%) \\
0(0 \%) \\
0(0 \%)\end{array}$ \\
\hline
\end{tabular}


Table 1. Cont.

\begin{tabular}{|c|c|c|c|c|}
\hline No. & Indicator & Variable & Peam Popech & Phlong \\
\hline \multicolumn{5}{|c|}{ 2. Status of fishery resources and management } \\
\hline \multirow[t]{6}{*}{2.1} & $\begin{array}{l}\text { Status of fisheries } \\
\text { resources }\end{array}$ & $\begin{array}{l}\text { Status of black fish abundance } \\
\text { compared to the past } 10 \text { years * }\end{array}$ & & \\
\hline & & Serious decline & $37(48.1 \%)$ & $38(45.8 \%)$ \\
\hline & & Small decline & $22(28.6 \%)$ & $40(48.2 \%)$ \\
\hline & & Remain stable & $2(2.6 \%)$ & $1(1.2 \%)$ \\
\hline & & Small increase & $6(7.8 \%)$ & $1(1.2 \%)$ \\
\hline & & High increase & $10(13.0 \%)$ & $3(3.6 \%)$ \\
\hline \multirow[t]{6}{*}{2.2} & & $\begin{array}{l}\text { Status of white fish abundance } \\
\text { compared to the past } 10 \text { years* }\end{array}$ & & \\
\hline & & Serious decline & $36(46.8 \%)$ & $39(47.0 \%)$ \\
\hline & & Small decline & $23(29.9 \%)$ & $40(48.2 \%)$ \\
\hline & & Remain stable & $1(1.3 \%)$ & $1(1.2 \%)$ \\
\hline & & Small increase & $9(11.7 \%)$ & $1(1.2 \%)$ \\
\hline & & High increase & $8(10.4 \%)$ & $2(2.4 \%)$ \\
\hline \multirow[t]{6}{*}{2.3} & & $\begin{array}{l}\text { Size of white fish compared to the } \\
\text { past } 10 \text { years }\end{array}$ & & \\
\hline & & Much smaller & $35(45.5 \%)$ & $45(54.2 \%)$ \\
\hline & & Smaller & $38(49.4 \%)$ & $33(39.8 \%)$ \\
\hline & & Remain similar size & $1(1.3 \%)$ & $4(4.8 \%)$ \\
\hline & & A little bigger & $2(2.6 \%)$ & $1(1.2 \%)$ \\
\hline & & Much bigger & $1(1.3 \%)$ & $0(0.0 \%)$ \\
\hline \multirow[t]{6}{*}{2.4} & & $\begin{array}{l}\text { Size of black fish compared to the } \\
\text { past } 10 \text { years* }\end{array}$ & & \\
\hline & & Much smaller & $17(22.4 \%)$ & $38(46.3 \%)$ \\
\hline & & Smaller & $55(72.4 \%)$ & $38(46.3 \%)$ \\
\hline & & Remain similar size & $2(2.6 \%)$ & $5(6.1 \%)$ \\
\hline & & A little bigger & $2(2.6 \%)$ & $1(1.2 \%)$ \\
\hline & & Much bigger & $0(0 \%)$ & $0(0 \%)$ \\
\hline \multirow[t]{6}{*}{2.5} & Engagement in social & $\begin{array}{l}\text { Number of households engaged } \\
\text { in an association * }\end{array}$ & & \\
\hline & community & Community fisheries & $70(90.9 \%)$ & $80(96.4 \%)$ \\
\hline & & Farming association & $0(0 \%)$ & $2(2.4 \%)$ \\
\hline & & Savings group & $42(54.5 \%)$ & $20(24.1 \%)$ \\
\hline & & Women's group & $16(20.8 \%)$ & $9(10.8 \%)$ \\
\hline & & Water management community & $12(15.6 \%)$ & $8(9.6 \%)$ \\
\hline \multirow[t]{6}{*}{2.6} & & $\begin{array}{l}\text { Number of households engaged } \\
\text { in different number of } \\
\text { associations }\end{array}$ & & \\
\hline & & Not engaged in any association & $5(6.5 \%)$ & $3(3.6 \%)$ \\
\hline & & Engage in 1 association & $24(31.2 \%)$ & $51(61 \%)$ \\
\hline & & Engage in 2 associations & $32(41.6 \%)$ & $19(22.9 \%)$ \\
\hline & & Engage in 3 associations & $12(15.6 \%)$ & $8(9.6 \%)$ \\
\hline & & Engage in 4 associations & $4(5.2 \%)$ & $2(2.4 \%)$ \\
\hline \multicolumn{5}{|c|}{ 3. Savings and Loans } \\
\hline \multirow[t]{6}{*}{3.1} & Financial status & $\begin{array}{l}\text { Concern about getting a loan from } \\
\text { a microfinance institution }\end{array}$ & & \\
\hline & & Agreed fully & $55(72.4 \%)$ & $54(65.9 \%)$ \\
\hline & & Agreed somewhat & $3(3.9 \%)$ & $7(8.5 \%)$ \\
\hline & & No idea & $4(5.3 \%)$ & $9(11.0 \%)$ \\
\hline & & Disagreed somewhat & $1(1.3 \%)$ & $3(3.7 \%)$ \\
\hline & & Disagreed completely & $13(17.1 \%)$ & $9(11.0 \%)$ \\
\hline
\end{tabular}


Table 1. Cont.

\begin{tabular}{|c|c|c|c|c|}
\hline No. & Indicator & Variable & Peam Popech & Phlong \\
\hline \multirow[t]{6}{*}{3.2} & & $\begin{array}{l}\text { Savings should be available to all } \\
\text { community members }\end{array}$ & & \\
\hline & & Agreed fully & $25(33.3 \%)$ & $37(44.6 \%)$ \\
\hline & & Agreed somewhat & $28(37.3 \%)$ & $30(36.1 \%)$ \\
\hline & & No idea & $4(5.3 \%)$ & $2(2.4 \%)$ \\
\hline & & Disagreed somewhat & $12(16 \%)$ & $8(9.6 \%)$ \\
\hline & & Disagreed completely & $6(8 \%)$ & $6(7.2 \%)$ \\
\hline \multirow[t]{6}{*}{3.3} & & $\begin{array}{l}\text { For the benefit of the community } \\
\text { as a whole, not everybody can } \\
\text { have equal access to savings }\end{array}$ & & \\
\hline & & Agreed fully & $16(21.3 \%)$ & $26(31.3 \%)$ \\
\hline & & Agreed somewhat & $34(45.3 \%)$ & $37(44.6 \%)$ \\
\hline & & No idea & $4(5.3 \%)$ & $6(7.2 \%)$ \\
\hline & & Disagreed somewhat & $19(25.3 \%)$ & $9(10.8 \%)$ \\
\hline & & Disagreed completely & $2(2.7 \%)$ & $5(6 \%)$ \\
\hline \multirow[t]{6}{*}{3.4} & & $\begin{array}{l}\text { The appropriate distribution of } \\
\text { loans should be prioritized over } \\
\text { individual relations with } \\
\text { community fisheries* }\end{array}$ & & \\
\hline & & Agreed fully & $31(40.8 \%)$ & $46(55.4 \%)$ \\
\hline & & Agreed somewhat & $24(31.6 \%)$ & $28(33.7 \%)$ \\
\hline & & No idea & $3(3.9 \%)$ & $3(3.6 \%)$ \\
\hline & & Disagreed somewhat & $17(22.4 \%)$ & $4(4.8 \%)$ \\
\hline & & Disagreed completely & $1(1.3 \%)$ & $2(2.4 \%)$ \\
\hline \multirow[t]{6}{*}{3.5} & & $\begin{array}{l}\text { Was the leadership of the savings } \\
\text { group strong? }{ }^{*}\end{array}$ & & \\
\hline & & Agreed fully & $32(42.7 \%)$ & $33(40.2 \%)$ \\
\hline & & Agreed somewhat & $25(33.3 \%)$ & $42(51.2 \%)$ \\
\hline & & No idea & $2(2.7 \%)$ & $1(1.2 \%)$ \\
\hline & & Disagreed somewhat & $16(21.3 \%)$ & $6(7.3 \%)$ \\
\hline & & Disagreed completely & $0(0 \%)$ & $0(0 \%)$ \\
\hline
\end{tabular}

$*$ denotes the existence of the difference between Peam Popech and Phlong based on the Chi-square test $\left(\mathrm{X}^{2}\right)$ with the significant level of 0.05 .

Table 2. Hypothesis testing of the income of the households.

\begin{tabular}{ccc}
\hline No. & Variables & Dry Season vs. Wet Season \\
\hline 1 & Number of households getting income & Prom fishing \\
2 & $\begin{array}{c}\text { Number of households getting income } \\
\text { from other livelihood activities }\end{array}$ & $\begin{array}{c}\text { Phlong } \\
\text { Peam Popech * } \\
\text { Phlong * }\end{array}$ \\
\hline
\end{tabular}

* denotes the existence of the difference between the dry and wet seasons based on the Chi-square test $\left(\mathrm{X}^{2}\right)$ with the significant level of 0.05 .

\subsection{The Characteristics of the Community Fisheries}

\subsubsection{Education}

The level of education of the community-fishery members in this study is defined in accordance with the official determination of Cambodian education. They were similar between the two communities, with more than half of the members not having finished primary school $(55.8 \%$ in Peam Popech and 51.3\% in Phlong) and 7.8\% in Peam Popech and 16.7\% in Phlong with no education at all (Table 1, No. 1.5). Other characteristics of the two community fisheries are described below: 


\subsubsection{Income and Livelihood Activities}

Number of households getting income from fishing was similar between the two communities and between both the dry and wet seasons (Table 1, No. 1.6 and 1.7, Table 2, No. 1), although fish was expectedly less abundant in the dry season. Small-scale fisheries can legally operate year-round in both the wet and dry seasons in lakes and river. The majority of the households, $61.6 \%$ in Peam Popech and between $48.2 \%$ and $54.2 \%$ in Phlong, gained up to $30 \%$ of their income from fishing in both the wet and dry seasons (Table 1, No. 1.6 and 1.7).

The community fishers made their living from integrated livelihood activities, such as farming rice and other crops, factory work, construction work, fish trading, making fishing gear, and livestock farming, depending on the opportunities available in both the wet and dry seasons (Table 1, No. 1.8 and 1.9; Table 2, No. 2). The livelihood opportunities in the two communities were different in both the wet and dry seasons (Table 2, No. 2). Community members up to 33\% earned their living from farming rice, other crops, and livestock (Table 1, No. 1.8 and 1.9).

One household may have up to six occupations a year (Table 1, No. 1.10 and 1.11). Some households, $35.1 \%$ and $39.8 \%$ in the dry season (Table 1 , No 1.10) and $5.2 \%$ and $12 \%$ in the wet season (Table 1, No. 1.11) in Peam Popech and Phlong, respectively, reported only one occupation. However, most households reported 2 occupations, $37.7 \%$ and $30.1 \%$ in the dry season (Table 1, No. 1.10) and $39 \%$ and $36.1 \%$ in the wet season (Table 1, No. 1.11) in Peam Popech and Phlong, respectively.

\subsubsection{Fish Consumption}

Most households in both community fisheries (39.8-55.4\%) preferred eating fish 3-7 days per week in both the dry and wet seasons (Table 1, No. 1.12 and 1.13). Less than $6.5 \%$ of the households consumed fish fewer than 3 days per week (Table 1, No. 1.12 and 1.13).

\subsubsection{Land Use for Agriculture}

In both communities, $10.9 \%$ to $45.1 \%$ of households owned $0.5-1.5$ ha of farmland (Table 1 , No. 1.14 ). Up to $3.1 \%$ of households owned $4-5$ ha of farmland and $5.6 \%$ to $14.1 \%$ of households owned 1.5-4 ha of farmland (Table 1, No. 1.14). Farmland is mainly rice farmland in lowland flooded areas. In both communities, a small number of households (up to $12.5 \%$ ) owned $0.5-4$ ha of cropland (Table 1, No. 1.15). The majority of households (26.3-52.6\%) possessed 0.5-1.5 ha of cropland (Table 1, No. 1.15). Cropland is the home lot and land near homes in upland areas, and usually used for planting vegetables and other crops and raising animals. The size of farmland was different between the two communities (Table 1, No. 1.14).

\subsubsection{Status of Fishery Resources and Management}

Most households (28.6-48.2\%) in both communities had slightly different opinions that both black and white fish had undergone either a small or a serious decline in abundance in the past 10 years (Table 1, No. 2.1 and 2.2). Few households (less than 13\%) observed stable or increased abundance of fish (Table 1, No. 2.1 and 2.2). Most households (22.4-72.4\%) in both communities perceived that both black and white fish had reduced in size (Table 1, No. 2.3 and 2.4). Only a minority of households (less than $6.1 \%$ ) claimed that fish size remained stable or increased (Table 1, No. 2.3 and 2.4). The opinion about abundance of white fish and size of black fish was different between the two communities (Table 1, No. 2.2 and 2.4). The black fish are sedentary fish species, which is black in color and tolerant of bad water quality, such as the striped snakehead (Channa striata) and blackskin catfish (Clarias meladerma). The white fish are migratory species, which are white in color and sensitive to changes in water quality, such as the thicklip barb (Probarbus labeamajor) and iridescent shark catfish (Pangasianodon hypophthalmus). These terms are usually used by rural Cambodians.

Almost all households (90.0-96.4\%) in both communities engaged in fishery management as members of community fishery (Table 1, No. 2.5), although their livelihood did not fully depend 
on fishing. Only up to $2.4 \%$ of the households were members of the farming association (Table 1 , No. 2.5), although rice farming was their most important livelihood activity. The second-highest percentage of households (54.5\% in Peam Popech and 24.1\% in Phlong) was members of a savings group. Several households, 20.8\% in Peam Popech and 10.8\% in Phlong, were members of women's groups (Table 1, No. 2.5). Each household could be involved in up to four different social associations, namely, community fisheries, farming association, savings group, and the women's group (Table 1, No. 2.6). Most households (22.9-61\%) engaged in only one or two social associations (Table 1, No. 2.6). The engagement in social community was different between the two communities (Table 1, No. 2.5).

\subsection{Savings and Loans}

Most community members (72.4\% in Peam Popech and 65.9\% in Phlong) expressed their concerns about obtaining a loan from a microfinance institution (Table 1, No. 3.1). A minority of the community members had little or no concern about this (Table 1, No. 3.1). This level of worry was similar between the two communities (Table 1, No. 3.1). The majority of members (33.3-37.3\% in Peam Popech and $36.1-44.6 \%$ in Phlong) suggested that savings should be made available to all members of the community (Table 1, No. 3.2). The remaining households (2.4-16\%) had no opinion or suggested an opposing idea (Table 1, No. 3.2).

For the general benefit of the community fisheries, most community members ( $21.3 \%$ and $45.1 \%$ in Peam Popech, $31.3 \%$ and $44.6 \%$ in Phlong) fully or partially agreed that all members of the community should not have equal rights to access the savings (Table 1, No. 3.3). The minority of households (less than $25.3 \%$ ) held the opposite opinion about access rights to savings (Table 1, No. 3.3.).

The majority of members (31.6\% and $40.8 \%$ in Peam Popech, 33.7\% and 55.4\% in Phlong) fully or partially agreed that the distribution of savings should be prioritized over each individual's relationship with the community fisheries, such as contribution to community fisheries including participation in fisheries-management activities, patrolling for illegal fishing, conservation of fishery resources (Table 1, No. 3.4). Most community members (33.3-42.7\% in Peam Popech and 40.2-51.2\% in Phlong) felt confident that the leadership of the current savings group was strong (Table 1, No. 3.5,). Less than $21.3 \%$ of the members had little or no confidence in the leadership of the savings group (Table 1 , No. 3.5). The opinion about the appropriate distribution of loans and the leadership was different between the two communities (Table 1, No. 3.4 and No. 3.5).

\section{Discussion}

\subsection{Characteristics of Community Fisheries}

The characteristics of community fisheries have important implications for livelihood development and fishery resource management. Fishing is a vital source of livelihood in rural communities [13]. Allison et al. (2012) mentioned that success in encouraging the participation of community fishers in fishery management requires that it address a direct threat to their livelihood [14]. Community fishers will become involved in community-fisheries management when they expect their livelihood to improve [15]. In addition, Allison et al. (2012) also reported that many factors that promote involvement in fishery management can be outside the scope of fishery policy or management institutions [14]. Some factors discussed here have no direct connection to fisheries. These include education, income, livelihood activities, and savings groups.

Most community-fisheries members were not highly educated and the percentage of households that had not completed primary school was much higher than the Cambodian national rate $51.3 \%$ and $55.8 \%$ vs. $25.8 \%$ ) [16]. However, the noneducation rate was lower than the national rate $(7.8 \%$ and $16.7 \%$ vs. $22.5 \%$ ) [16]. The 2013 Cambodian population census reported that the literacy rate was lower in agriculture, forestry, and fisheries [16]. Education is essential for sustainable economic development [16]. Human capacity and skill development is a key element in promoting livelihood 
development and participation in community-fisheries management [17]. Low skill and education levels are a challenge in the implementation of fisheries comanagement.

Community fishers utilize fish for food and to earn family income [14]. Fishing is linked closely with rural-community livelihoods. Cambodians eat $67 \mathrm{~kg}$ fish/person/year [6]. This study found that rural-community fishers ate fish 3-7 days per week. This frequency of fish consumption was consistent with the 2013 agriculture census in Cambodia, which reported that $90 \%$ of farming households in the Tonle Sap region engaged in fishing for fish, snails, crustaceans, crabs, freshwater shrimp, etc., for family consumption and ate fish and other seafood four days per week [18]. A study by WorldFish (2016) reported that a household with insufficient income consumed floodplain resources such as snails, shellfish, crabs, and snakes more frequently than other meats, such as wild animals or birds [19]. Those resources can be found in the flooded grassland, marshland, and deep pools or small lake habitats in the Tonle Sap Floodplain [20]. The report added that Cambodians ate more than twice as much fish as pork, chicken, or beef (15.7 kg/person/year for these three items) [19]. Notably, when food and income is not secure, fishers will employ destructive fishing methods, as demonstrated in Bangladesh [21]. Surprisingly, $83 \%$ of interviewees in the Philippines said they would not stop fishing although other occupations could generate higher income [22]. People value fisheries when it is vital for their livelihoods [23].

In addition to food consumption, fishing provided an annual family income of around US\$589-1433 [16]. The money gained from fishing is not only used as family cash income, but also to buy fuel, rice seeds, and fertilizer for rice farming. The income from fishing contributed to a household requirement but provided only part of the family income because a household generally needs five times as much as the income from fishing, when considering the Cambodian GDP per capita in 2016 (US\$1269.9) [24]. The average family size in Cambodia is five persons [16]. Tietze (2016) found that in most cases, fishing did not provide sufficient income for the household's needs [25]. Diverse economic activities were necessary to fulfill family needs, and most community fishers both fished and farmed. When a household has access to diverse income opportunities, it is less sensitive to the effects of climate change [26] and when a community depends highly on nutrition, income, and employment from fishery, they are more sensitive to the effects of climate change [27]. Typically, a household has more than one occupation, and may grow crops, run a small business, or raise cattle, pigs, chickens, or ducks in their home lots. Seventy-eight percent of the households in the Tonle Sap region raised livestock and/or poultry [28]. They performed other fishery-related activities, such as fish processing and marketing [10]. Hap et al. (2016) [29] and MeKenney and Tola (2002) reported that there was a need for community fishers to perform many economic activities to earn a living [30]. The diversified livelihoods of these rural communities were also reported by Marschke and Berkes (2005) [15]. This study found that most rural households in the two communities owned farmland of approximately 0.5-1.5 ha and cropland of a similar size. This finding was similar to the 2013 census of agriculture in Cambodia, which found that rural Cambodians owned an average of 1.64 ha of farmland [11]. Rice-production yield, on average, is 4.2 tons per hectare [11]. Cambodians consumed an average of $143 \mathrm{~kg}$ rice/person/year [16]. This allows for a surplus of rice to exchange for some household income. These diverse livelihood activities may contribute to improved fishery management, as it could divert some efforts to alternative appropriate occupations and relieve the pressure on natural resources [15]. Tietze (2016) suggested that alternative livelihood opportunities are a priority for improving fisheries conservation and management [25]. In the case of the two communities, the savings group provides some fund for livelihood activities and fishery management. In addition, it is important to have effective fishery-management measures.

Although the income of the two rural communities did not depend fully on fishing, members of the community fisheries were likely to focus on fisheries. Almost all community members were members of community fisheries, more than any other social associations. Effective fishery comanagement requires the involvement and active participation of local community members [15,31]. It is essential to obtain the involvement of the direct users of fishery resources. The community members found 
it important to manage the fishery resources in their communities to maintain their livelihoods. Community fishers are legally expected to participate in fishery conservation and management and are concerned about the decline of fish stocks. These community fishers could report the historical status of fishery resources in their communities. Their observation of fish-catch decline confirmed the report by Marschke and Berkes (2005) [15]. The decline in fish abundance and size was addressed in 2002 by Zalinge et al. (2002) [4]. The 2006 Cambodian fishery law provides community fishery members with rights and the responsibility to manage fishery resources in their designated fishing grounds $[9,32]$. Community fisheries are expected to develop their own fishery management plan [6]. Community fisheries are responsible for developing, managing, conserving, and utilizing fishery resources in their designated area in a sustainable manner $[9,32]$. The community fishers are required to protect the fish habitat and ecosystem, participate in the monitoring and the control of fishery resources, and prevent destructive activities $[9,32]$.

\subsection{Savings Groups and Loans}

Savings groups and microcredit options were implemented in the two community fisheries. The establishment and implementation of savings groups were facilitated and supported by the provincial fishery cantonment and nongovernmental organizations [33]. The concern of the community fishers about taking loans may be related to their debt. The incurrence of debt may be connected with agriculture and other business activities, but not fisheries [19]. A rural fishing-dependent household in the Tonle Sap region had an average debt of US\$372 [19], which was one third of their national GDP per capita of US\$1269.9. Community fishers receive loans for their family's needs and for buying rice seeds, pesticides and fuel for farming, livestock production, education, healthcare, and to pay other debts $[17,34]$. Savings in community fisheries are different from agricultural savings because part of the interest earned from the loans is used for fisheries management and the conservation of community fisheries. The savings group is a useful activity in community fisheries [17].

The experiences of a savings group in Bantoat Bos Village, Cambodia showed that, with the help of a savings group, a poor community member who was not in the habit of saving money could do it and gain access to a loan [34]. The loan relieved financial difficulty and could be used to generate more income from raising livestock and growing vegetables [34]. The current savings implemented in those communities by the Sustainable Community International program was small. However, it was appreciated by the community fishers, as it was easy to access without collateral. A study in Pakistan showed that although microcredit was small, it had a positive effect on poverty reduction [35]. This community savings fund could help relieve the stress of paying off other debts. The savings group also provides an incentive for strengthening local community fisheries and solidarity. A study on the sustainability of the Elephant Marsh Fisheries in Malawi suggested that a strong local institution has a strong effect on the sustainability of fisheries management [36].

According to the Cambodian sub-decree on community fisheries, the budget needed for community fisheries to implement their action plans permits the communities to seek technical and financial support from charities, government, nongovernmental organizations, international organizations, and other legal sources [9]. The communities can also collect contributions from their community members as a membership fee [9]. Engaging in fishery ecolabeling could be an opportunity to access additional sustainable sources of funding for implementing community fisheries' action plans. The savings group must be sustained so that it can sustain the community fisheries fund.

Funding from the savings group is part of a solution to relieve budget shortages in community fisheries. However, this study found some concerns among community households about the savings operation. These concerns were about the rights of community members to access the savings and their distribution. Consultation meetings should be conducted with members of savings groups to gather their opinions and collect further details about the current internal rules and regulations of savings groups. Any implementation procedures should be agreed to by all members. Archer (2012) reported 
the recommendations of the Community Development Fund that the funds should be managed in a way that the community members play an active role, and therefore, adapt to the system [37].

In this regard, a study of savings groups in Cambodian agricultural production in 2012 by OXFAM [12] suggested that, to ensure good operation and sustainability of the savings group, the implementation arrangement and procedure should consider the following:

- Group size: some savings groups failed because there were too few group members. A larger number of group members were found to accumulate larger funds and could more quickly fulfill the demand for giving loans. However, the most suitable size for the group is 15-25 members [38].

- Lending to nonmembers: past experiences of lending to nongroup members gave both a good advantage and high risk. However, it depended on the decision of the group members and the availability of money.

- Rules and procedure: holding regular meetings and more participation in meetings showed a stronger organization. The rules and regulations, such as to have regular meetings and to return loans and deposit money in a timely manner, were implemented to reinforce the activities of the savings group. However, in some cases, punishment would cause tension within the group. Meetings are essential to keep members well-informed, improve communication among members, and to understand the importance of savings for the community.

- Committee or leadership of savings group: Trust and belief is very important in the savings group. The savings and loans must have accurate records and accountability. This is to build trust and belief. It is essential that the leader or committee is good at conflict resolution and has financial or book-keeping skills. Females were found to be good recorders and good leaders of saving groups [17]. Capacity building should be conducted to enhance accounting and book-keeping.

- Available funds: the savings should make funds available, which can be mobilized among group members.

Funding from a savings group is financial capital for reinvesting in livelihood activities such as fishing, farming, livestock, and small businesses. The fishers and farmers joined a network or association to work together as community fisheries and savings groups. They joined such networks or associations to maintain the sustainability of their natural assets. Livelihood was defined by Scoones (1998) [39] as consisting of the capabilities, assets, and activities required for a means of living. Scoones (1998) added that livelihood strategies can be implemented depending on the basic material and social, tangible, and intangible assets that people possessed [39]. Fishery resources, farmland, and cropland are the assets these communities own and use for their livelihood.

\section{Conclusions}

The characteristics of the two community fisheries, Peam Popech and Phlong, were relevant factors for the successful implementation of community-fisheries management and livelihood development. The community fisheries members did not fully depend on fishing; however, it was a very important source of food and income for the rural households. Part of the income from fishing was invested in other economic activities. Facing the problem of fish decline, this study suggests that fishery management shall be further strengthened to maintain sustainable fishery resources for the communities.

The findings from this study suggested that the implementation arrangement and procedure should be reviewed and strengthened to encourage the active participation of savings group members. The procedure should reflect the opinion and perceptions of the savings group members and incorporate experiences from elsewhere. A shortage of funds is an obstacle to livelihood activities and community-fisheries management. The part of the savings fund is used for sustainable fisheries management. Funding from a savings group may help relieve the stress of financial shortages in community fisheries. Loans from these savings were used by the community fisheries members to invest in diverse livelihood activities to generate more family income. The government should have a 
national financial policy to facilitate community fishers in investing in their fishery-related activities. The lessons learnt from these community fisheries will be beneficial to other communities elsewhere.

Supplementary Materials: The following are available online at http:/ /www.mdpi.com/2071-1050/10/8/2905/ s1, Questionnaire S1: Questionnaire for the Interview, Peam Popech and Phlong Community Fisheries, Kampong Chhnang Province, Cambodia.

Author Contributions: Conceptualization, S.L.; methodology, S.L.; software, S.L.; validation, N.Y.; formal analysis, S.L.; investigation, S.L. and A.M.; resources, S.L. and N.Y.; data curation, S.L. and A.M.; writing-original draft preparation, S.L.; writing-review and editing, S.L. and N.Y.; visualization, S.L.; supervision, N.Y.; project administration, N.Y.; funding acquisition, N.Y.

Funding: This research was funded by Japan Society for the Promotion of Science (JSPS) Kakenhi in Japan, grant number $16 \mathrm{H} 02565$.

Acknowledgments: The authors would like to thank Jay D. Hastings for initiating the savings groups for the community fisheries in Kampong Chhnang Province, Cambodia, Jotra Sou and Chan Ratana Cambodian Fisheries Administration for mapping and data collection, Som Phirun, Prak Leang Hour, Chamroeun, and Sothea Vy, and Kampong Chhnang Provincial Fisheries Cantonment for facilitating relevant work and participating in data collection, and Miyoko Masui and the University of Tokyo for administrative support.

Conflicts of Interest: The authors declared no conflicts of interest.

\section{References}

1. Thuok, N.; Lieng, S. Fish and the Poor: The case of Cambodia. In Poverty Reduct. Through Sustain. Fish. Emerg. Policy Gov. Issues Southeast Asia; Institute of Southeast Asian Studies: Singapore, 2008; pp. 39-50. Available online: https: / / www.scopus.com/inward / record.uri?eid=2-s2.0-84894926570\&partnerID=40\& md5=d71f86569cf15488deadad2160fada26 (accessed on 24 May 2018).

2. World Bank. Cambodia Overview. 2005. Available online: http://www.worldbank.org/en/country/ cambodia/overview (accessed on 5 May 2018).

3. Swan, J.; Greboval, D. Overcoming Factors of Unsustainability and Overexploitation in Fisheries: Selected papers on issues and approaches. 2005. Available online: http://www.fao.org/docrep/009/a0312e/ A0312E00.htm (accessed on 24 May 2018).

4. Van Zalinge, N.; Thuok, N.; Nuov, S. Update on the Status of the Cambodian Inland Capture Fisheries Sector with Special Reference to the Tonle Sap Great Lake. Catch Cult. 2002, 8, 1-30. Available online: http:/ / wwvv.mekonginfo.org/assets / Publications/Catch-and-Culture/catchdec02vol8.2.pdf (accessed on 24 April 2018).

5. Lieng, S.; Zalinge, V.N. Fish Yield Estimation in the Floodplains of the Tonle Sap Great Lake and River. 2001, pp. 18-21. Available online: http:/ / www.mekonginfo.org/assets/midocs/0003333-biota-fish-yieldestimation-in-the-floodplains-of-the-tonle-sap-great-lake-and-river-cambodia.pdf (accessed on 24 May 2018).

6. Hortle, K.G.; Lieng, S.; Valbo-Jorgensen, J. An Introduction to Cambodia's Inland Fisheries; Mekong Development Series No. 4; Mekong River Commission: Phnom Penh, Cambodia, 2004, ISSN 1680-4023.

7. FAO. Interactive Mechanisms for Small-Scale Fisheries Management: Report of the Regional Consultation; FAO Regional Office for Asia and the Pacific: Bangkok, Thailand, 2002. RAP Publication 2002/10, 2002. Available online: http:/ / www.fao.org/apfic/publications/detail/en/c/419435/ (accessed on 24 May 2018).

8. Baran, E. Cambodia Inland Fisheries: Facts, Figures and Context; WorldFish Center and Inland Fisheries Research and Development Institute: Phnom Penh, Cambodia, 2005.

9. Royal Government of Cambodia. Sub-Decree on Community Fisheries. No 25 OrNor Kror BorKor. 2005. Available online: https://www.ajne.org/sites/default/files/resource/laws/7210/sub-decree-80on-community-fisheries-management.pdf (accessed on 16 August 2018).

10. Case Study Facilitating Co-Management in Cambodian Community Fisheries-the RFLP Experience, (n.d.). Available online: http:/ / www.fao.org/3/a--ar503e.pdf (accessed on 9 May 2018).

11. Emerging Markets Consulting. Sustainability Study of Savings Group Programs in Cambodia; Emerging Markets Consulting: Phnom Penh, Cambodia, 2012. Available online: https://www.oxfamamerica.org/static/ media/files/Sustainability_Study_of_Savings_Groups_Program_in_Cambodia.pdf. (accessed on 1 May 2018). 
12. Sou, J. Map Showing the Locations of the Peam Popech and Phlong Community Fisheries; Fishery Administration, No. 186; Preah Norodom Blvd. Sangkat Tonle Bassac. Khan Chamcar Morn: Phnom Penh, Cambodia, 2018.

13. Sok, S.; Yu, X.; Wong, K.K. Impediments to Community Fisheries Management: Some Findings in Kompong Pou Commune, Krakor District in Cambodia's Tonle Sap, Singap. J. Trop. Geogr. 2012, 33, 398-413. [CrossRef]

14. Allison, E.H.; Ratner, B.D.; Åsgård, B.; Willmann, R.; Pomeroy, R.; Kurien, J. Rights-based Fisheries Governance: From Fishing Rights to Human Rights. Fish Fish. 2012, 13, 14-29. [CrossRef]

15. Marschke, M.; Berkes, F. Local Level Sustainability Planning for Livelihoods: A Cambodian Experience. Int. J. Sustain. Dev. World Ecol. 2005, 12, 21-33. [CrossRef]

16. Cambodia INTER_CENSAL Survey; National Institute of Statistics, Ministry of Planning: Phnom Penh, Cambodia, 2014. Available online: http://www.stat.go.jp/info/meetings/cambodia/pdf/c13ana07.pdf (accessed on 1 May 2018).

17. Kurien, J. Community Fisheries Organizations of Cambodia; Food Agric. Organization United Nations: Rome, Italy, 2017; Available online: http:/ / www.fao.org/3/a--i7206e.pdf (accessed on 15 November 2017).

18. FAO. Census of Agriculture of the Kingdom of Cambodia 2013; FAO: Phnom Penh, Cambodia, 2015. Available online: http://www.nis.gov.kh/nis/CAC2013/CAC_2013_Final_Report_En.pdf (accessed on 4 May 2018).

19. Mousset, E.; Rogers, V.; Saray, S.; Ouch, K.; Srey, S.; Mith, S.; Baran, E. Roles and Values of Fish in Rural Welfare in Cambodia (Welfare Data Analysis); Inland Fisheries Research and Development Institute (Fisheries Administration) and WorldFish (WFC): Phnom Penh, Cambodia, 2016; p. 102.

20. Lieng, S.; Hua, P.L.; Roth, T.; Hortle, K.G. Standing Crop and Fish Species Association in Cambodian Floodplains. Fish. Res. 2005, 33-46. Available online: http://archive.iwlearn.net/mrcmekong.org/ download/free_download/proceedings_7TechSym/paper2--Standing--cop--n--fish--species.pdf (accessed on 24 May 2018).

21. Islam, M.M.; Aktar, R.; Nahiduzzaman, M.; Barman, B.K.; Wahab, M.A. Social Considerations of Large River Sanctuaries: A Case Study from the Hilsa Shad Fishery in Bangladesh. Sustainability 2018, 10, 1-17. [CrossRef]

22. Pomeroy, R.S.; Pollnac, R.B.; Katon, M.; Predo, C.D. Evaluating Factors Contributing to the Success of Community-based Coastal Resource Management: The Central Visayas Regional Project-1. Philipp. Ocean Coast. Manag. 1997, 36, 97-120. [CrossRef]

23. Van Holt, T.; Weisman, W.; Johnson, J.C.; Käll, S.; Whalen, J.; Spear, B.; Sousa, P. A Social Wellbeing in Fisheries Tool (SWIFT) to Help Improve Fisheries Performance. Sustainability 2016, 8, 1-15. [CrossRef]

24. GDP Per Capita, n.d. Available online: https://data.worldbank.org/indicator/NY.GDP.PCAP.CD (accessed on 13 May 2018).

25. Tietze, U. Technical and Socio-Economic Characteristics of Small-Scale Coastal Fishing Communities, and Opportunities for Poverty Alleviation and Empowerment. 2016. Available online: http://www.fao.org/3/a-i5651e.pdf\%5Cnpapers3: / / publication/uuid/5B829B94--2C08--4312--9EC4--4987D900C923 (accessed on 10 April 2018).

26. Ndhlovu, N.; Saito, O.; Djalante, R.; Yagi, N. Assessing the Sensitivity of Small-scale Fishery Groups to Climate Change in Lake Kariba, Zimbabwe. Sustainability 2017, 9, 1-18. [CrossRef]

27. Islam, M.; Sallu, S. Vulnerability of Fishery-based Livelihoods to the Impacts of Climate Variability and change: Insights from Coastal Bangladesh. Reg. Environ. Chang. 2014, 14, 281-294. [CrossRef]

28. National Institute of Statistics. General Population Census of Cambodia 2008; Ministry of Planning: Phnom Penh, Cambodia, 2009.

29. Hap, N.; Un, S.; Nasielski, J. A Review of Socioeconomic Studies in the Fisheries Sector in Cambodia. 2016. Available online: http:/ / pubs.iclarm.net/resource_centre/WF--4074.pdf (accessed on 2 May 2018).

30. McKenney, B.; Tola, P. Natural Resources and Rural Livelihoods in Cambodia; CDRI: Phnom Penh, Cambodia, 2002; pp. 1-120, ISSN 1560-9197.

31. Barakagira, A.; de Wit, A.H. Community Livelihood Activities as Key Determinants for Community Based Conservation of Wetlands in Uganda. Environ. Socio-Econ. Stud. 2017, 5, 11-24. [CrossRef]

32. Law on Fisheries. Royal Government of Cambodia. 2006. Available online: http://extwprlegs1.fao.org/ docs/pdf/cam82001.pdf (accessed on 6 December 2016).

33. Sreyphea, C.; Panha, T.; Diepart, J.-C. Fisheries Reforms and Rights-Based Fisheries: Insights from Community Fisheries Across Cambodia; The Learning Institute: Phnom Penh, Cambodia, 2016. 
34. Saving for Change Helps Communities in Cambodia Address Financial Difficulty. Available online: https: / / www.oxfamamerica.org/explore/stories/saving-for-change-helps-communities-in-cambodiaaddress-financial-difficulty / (accessed on 1 May 2018).

35. Latif, A.; Nazar, M.S.; Mehmood, T.; Shaikh, F.M.; Shah, A.A. Sustainability of Micro Credit System in Pakistan and Its Impact on Poverty Alleviation. J. Sustain. Dev. 2011, 4, 160-165. [CrossRef]

36. Kosamu, I.B.M. Conditions for Sustainability of the Elephant Marsh Fishery in Malawi. Sustainability 2014, 6, 4010-4027. [CrossRef]

37. Archer, D. Finance as the Key to Unlocking Community Potential: Savings, Funds and the ACCA Programme. Environ. Urban. 2012, 24, 423-440. [CrossRef]

38. Ledgerwood, J.; Rasmussen, S. Savings Groups. 2011. Available online: http://www.cgap.org/blog/savings-groups (accessed on 1 May 2018).

39. Scoones, I. Sustainable Rural Livelihoods: A Framework for Analysis; IDS Working Paper No. 72; IDS: Brighton, UK, 1998; Available online: http:/ / www.ids.ac.uk/files/dmfile/Wp72.pdf (accessed on 23 May 2018).

(C) 2018 by the authors. Licensee MDPI, Basel, Switzerland. This article is an open access article distributed under the terms and conditions of the Creative Commons Attribution (CC BY) license (http:/ / creativecommons.org/licenses/by/4.0/). 